\title{
KAJIAN SOSIAL EKONOMI TERHADAP POTENSI DAN PEMANFAATAN SUMBER DAYA ALAM LAUT DAN PESISIR DI PULAU BEBALANG KECAMATAN MANGANITU SELATAN KABUPATEN KEPULAUAN SANGIHE
}

\author{
Socio-Economic Study of the Potential and Utilization of Marine and Coastal \\ Natural Resources at Bebalang Island, Manganitu Selatan District, Sangihe Island Regency
}

\author{
Eunike Irene Kumaseh ${ }^{1)}$, Costantein Imanuel Sarapil' ${ }^{1),}$ Ganjar Ndaru Ikhtiagung'), \\ Erlin Puspaputri ${ }^{3)}$ \\ ${ }^{1}$ Program Studi Teknologi Penangkapan Ikan, Politeknik Negeri Nusa Utara \\ Jl. Kesehatan No. 1 Kelurahan Sawang Bendar, Tahuna, 95812 \\ ${ }^{2}$ Politeknik Negeri Cilacap Jl. Dr. Sutomo No. 1 Sidakaya, Cilacap 537992, Indonesia \\ ${ }^{3}$ Direktorat Kelembagaan, Ditjen Dikti, Kementerian Pendidikan dan Kebudayaan, \\ Gedung Dikti, Pintu Satu Senayan, Jl. Jenderal Sudirman, Jakarta 10270 \\ Email: sarapilcostantein79@gmail.com
}

\begin{abstract}
Abstrak: Penelitian ini bertujuan untuk mengkaji potensi pemanfaatan sumber daya alam laut dan pesisir di Pulau Bebalang Kecamatan Manganitu Selatan Kabupaten Kepulauan Sangihe Propinsi Sulawesi Utara. Pengambilan data dilakukan dengan cara mengumpulkan data secara langsung melalui wawancara dan observasi di tengah masyarakat Pulau Bebalang. Metode penelitian yang digunakan yaitu deskriptif kualitatif dan menggunakan analisis SWOT dalam pengambilan keputusan untuk pengembangan Pulau Bebalang. Pengambilan data dilakukan dengan mengumpulkan data primer di Kantor Kampung Bebalang, serta kuisioner yang dijalankan untuk 40 orang masyarakat Kampung Bebalang. Pemanfaatan sumber daya alam pesisir dan bawah laut di Pulau Bebalang merupakan gabungan aspek lingkungan, sumber daya manusia, serta faktor sosial ekonomi masyarakat. Potensi wilayah pesisir seperti pantai berpasir, serta potensi bawah laut di Pulau Bebalang seperti kekayaan terumbu karang dan lamun, dapat dikembangkan ke berbagai bidang seperti wisata bahari, tour \& travel, konservasi, dan lain sebagainya. Namun, perlu juga memperhatikan adanya ancaman. Rekomendasi strategi untuk pengembangan potensi Pulau Bebalang berada pada kuadaran I artinya Progresif. Hal ini menunjukkan bahwa pengembangan potensi Pulau Bebalang dalam kondisi prima dan mantap sehingga dapat berkembang lebih maju. Kondisi ini memungkinkan dalam peningkatan pendapatan masyarakat sambil tetap menjaga kelestarian lingkungan.
\end{abstract}

Kata kunci: kajian sosial ekonomi; potensi; pemanfaatan sumber daya; pulau bebalang.

Abstract: This study aims to examine the potential utilization of marine and coastal natural resources in Bebalang Island, Manganitu Selatan District, Sangihe Islands Regency, North Sulawesi Province. Data was collected by collecting data directly through interviews and observations in the community of Bebalang Island. The research method used is descriptive qualitative and uses SWOT analysis in making decisions for the development of Bebalang Island. Data were collected by collecting primary data at the Bebalang Village Office, as well as a questionnaire which was run for 40 people from Bebalang Village. The utilization of coastal and underwater natural resources on Bebalang Island is a combination of environmental aspects, human resources, and community socioeconomic factors. The potential of coastal areas such as sandy beaches, as well as the underwater potential of Bebalang Island, such as the richness of coral reefs and seagrass, can be developed into various fields such as marine tourism, tours \& travel, conservation, and so on. However, it is also necessary to pay attention to threats. The recommended strategy for developing the potential of Bebalang Island is in the I consciousness, which means Progressive. This shows that the development of Bebalang Island's potential is in a prime and steady condition so that it can develop more advanced. This condition makes it possible to increase people's income while maintaining environmental sustainability.

Keyword: socio-economy study; potential; utilization of resources; Bebalang island. 


\section{PENDAHULUAN}

Wilayah pesisir merupakan daerah strategis karena merupakan wilayah peralihan (interface) antara ekosistem darat dan laut, dimana potensi sumber daya alam dan jasa lingkungannya sangat besar (Sutrisno, 2014). Pengembangan wilayah pesisir dan laut merupakan aset yang sangat besar (Arif, 2008). Pemanfaatan sumberdaya pesisir seperti upaya - upaya konservasi, pemberdayaan ekonomi lokal serta pemeliharaan kultur dan budaya (Satria, 2009).

Kabupaten Kepulauan Sangihe merupakan bagian integral dari Propinsi Sulawesi Utara dengan ibukota Tahuna. Berjarak sekitar 142 mil Laut dari Ibukota Propinsi Sulawesi Utara, Manado, terletak antara $2^{\circ} 4^{\prime} 13^{\prime \prime}-4^{\circ} 44^{\prime} 22^{\prime \prime}$ Lintang Utara dan $125^{\circ}$ 9' $28^{\prime \prime}-125^{\circ} 56^{\prime} 57^{\prime \prime}$ Bujur Timur, berada diantara Pulau Sulawesi dan Mindanao (Republik Philipina), sehingga Kabupaten Kepulauan Sangihe dapat dikategorikan "Daerah Perbatasan". Kemudian di samping daerah perbatasan, dua karateristik lain yang cukup signifikan membedakan dengan Kabupaten/Kota lain yaitu daerah kepulauan dan daerah Rawan Bencana Alam (BPS Kabupaten Kepulauan Sangihe, 2019).

Secara administratif, Pulau Bebalang termasuk dalam wilayah pemerintahan Kecamatan Manganitu Selatan Kabupaten Kepuluan Sangihe. Menurut Data BPS Kabupaten Kepulauan Sangihe (2019), Pulau Bebalang mempunyai luas wilayah sebesar $3,40 \mathrm{~km}^{2}$ dengan jumlah penduduk sebanyak 418 jiwa.

Tabel 1. Jumlah Penduduk menurut Mata Pencaharian.

\begin{tabular}{|l|l|c|c|}
\hline No. & $\begin{array}{c}\text { Jenis } \\
\text { Pekerjaan }\end{array}$ & $\begin{array}{c}\text { Jumlah } \\
\text { (orang) }\end{array}$ & $\begin{array}{c}\text { Persentase } \\
(\%)\end{array}$ \\
\hline 1 & Petani & 53 & 12,86 \\
\hline 2 & Nelayan & 250 & 60,68 \\
\hline 3 & Pedagang & 4 & 0,97 \\
\hline 4 & PNS & 5 & 1,21 \\
\hline 5 & Lainnya & 100 & 24,27 \\
\hline \multicolumn{2}{r|}{ Total } & $\mathbf{4 1 2}$ & $\mathbf{9 9 , 9 9}$ \\
\hline
\end{tabular}

Berdasarkan pada Tabel 1, dapat dilihat bahwa sebagian besar penduduk Pulau Bebalang bekerja sebagai nelayan, dengan persentase 60,68 persen. Sementara, masyarakat yang bekerja sebagai pedagang dengan persentase paling rendah yaitu 0,97 persen.

Pengembangan wilayah pesisir berbasis sumberdaya lokal dapat meningkatkan partisipasi masyarakat dan pengawasan potensi sumberdaya, sehingga seimbang antara pendapatan dan pelestarian sumberdaya (Stanis, 2005). Penelitian ini bertujuan untuk mengkaji potensi dan pemanfaatan sumber daya laut dan pesisir di Pulau Bebalang Kecamatan Manganitu Selatan Kabupaten Kepulauan Sangihe.

\section{METODE PENELITIAN}

Penelitian ini dilaksanakan selama bulan April - September Tahun 2020 di Pulau Bebalang Kecamatan Manganitu Selatan Kabupaten Kepulauan Sangihe. Lokasi penelitian ditunjukkan pada Gambar 2 sebagai berikut.

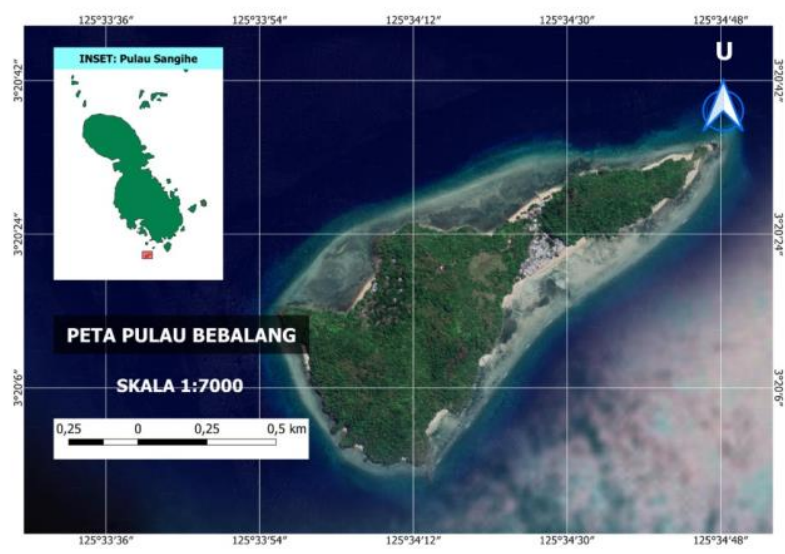

Gambar 1. Lokasi Penelitian

Metode penelitian yang digunakan yaitu deskriptif kualitatif dan menggunakan analisis SWOT dalam pengambilan keputusan untuk pengembangan Pulau Bebalang. Pengambilan data dilakukan dengan cara mengumpulkan data secara langsung melalui wawancara dan observasi di tengah masyarakat Pulau Bebalang. Pengambilan data dilakukan dengan mengumpulkan data primer di Kantor Kampung Bebalang, serta kuisioner yang dijalankan untuk 40 orang masyarakat Kampung Bebalang.. Menurut Bungin (2008), wawancara yaitu proses memperoleh keterangan untuk tujuan penelitian dengan cara Tanya 
jawab sambil bertatap muka antara pewawancara dengan informan atau orang yang diwawancarai, dengan atau tanpa menggunakan pedoman (guide) wawancara, dimana pewawancara dan informan terlibat dalam kehidupan sosial yang relatif lama. Paling utama di dalam melakukan wawancara adalah memperhatikan kemampuan pewawancara dalam mengendalikan wawancaranya. Ini disebabkan efektifitas wawancara banyak tergantung pada pewawancara.

Pengambilan data juga dilakukan dengan cara observasi atau pengamatan yaitu kegiatan keseharian manusia dengan menggunakan panca indera mata sebagai alat bantu utamanya selain panca indera lainnya seperti telinga, penciuman, mulut, dan kulit. Karena itu, obervasi adalah kemampuan seseorang untuk menggunakan pengamatannya melalui hasil kerja pancaindra mata serta dibantu dengan pancaindra lainnya untuk menghimpun data penelitian.

Data - data yang dibutuhkan adalah sebagai berikut.

a) Gambaran umum Pulau Bebalang.

b) Potensi alam apa saja yang ada di Pulau Bebalang.

c) Kearifan Lokal dan nilai - nilainya yang ada di Pulau Bebalang.

Analisis potensi dan pemanfaatan sumber daya laut dan pesisir menggunakan analisis SWOT, yaitu analisis dengan melihat faktor - faktor yang menjadi kekuatan (strength), kelemahan (weakness), peluang pengembangan (opportunities), serta faktor - faktor ancaman (threats) (Rangkuti, 2011 dalam Hermawan, 2017), seperti yang ditunjukkan pada Gambar 3 . Menurut Suwarsono (2008) dalam Sulistyo (2017), langkah - langkah dalam penyusunan matriks SWOT yaitu sebagai berikut.

1. Membuat indikator dari variabel lingkungan internal dan eksternal yang diperkirakan mempengaruhi masa depan.

2. Memberikan bobot pada setiap indikator dengan membandingkan peran satu indikator dengan indikator lainnya.

3. Memberikan penilaian terhadap besar kecilnya sumbangan atau hambatan oleh tiap indikator.
Penilaian dimulai dari nilai $1-5$, dimana nilai 1 2 merupakan kelemahan dan ancaman, $3-5$ merupakan kekuatan dan peluang.

4. Menghitung nilai tertimbang dari tiap indikator dalam satu kategori dan menjumlahkannya. Nilai tertimbang merupakan hasil perkalian antara bobot dan nilai masing - masing indikator.

5. Menentukan posisi perusahaan dalam satu kuadran dan melakukan strategi yang sebaiknya dilakukan.

\section{HASIL DAN PEMBAHASAN}

\section{Gambaran Umum Pulau Bebalang}

Pulau Bebalang mempunyai luas wilayah 60,1 ha, termasuk dalam wilayah adminitrasi Kecamatan Manganitu Selatan, Kabupaten Kepulauan Sangihe. Batas - batas wilayah yaitu sebagai berikut.

- Utara : Kampung (Pulau) Mahumu

- Selatan : Laut Sulawesi

- Timur : Kampung (Pulau) Batunderang

- Barat : Laut Sulawesi

Jumlah penduduk berdasarkan tingkat pendidikan ditunjukkan pada Gambar 2. Dapat dilihat pada Gambar 2, sebagian besar penduduk di Pulau Bebalang mempunyai tingkat pendidikan Sekolah Dasar (SD).

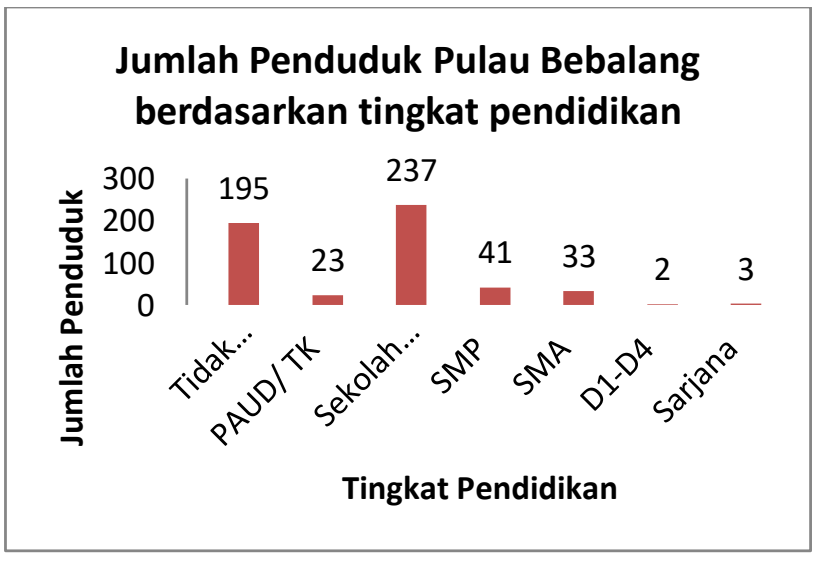

Gambar 2. Jumlah penduduk di Pulau Bebalang berdasarkan Tingkat Pendidikan.

\section{Potensi Wilayah Pesisir Pulau Bebalang}

Potensi wilayah pesisir di Pulau Bebalang, dapat dilihat pada Gambar 3, yaitu pantai berpasir, pulau kecil sebagai perlindungan pantai, kawasan konservasi dan pengembangan marikultur. 

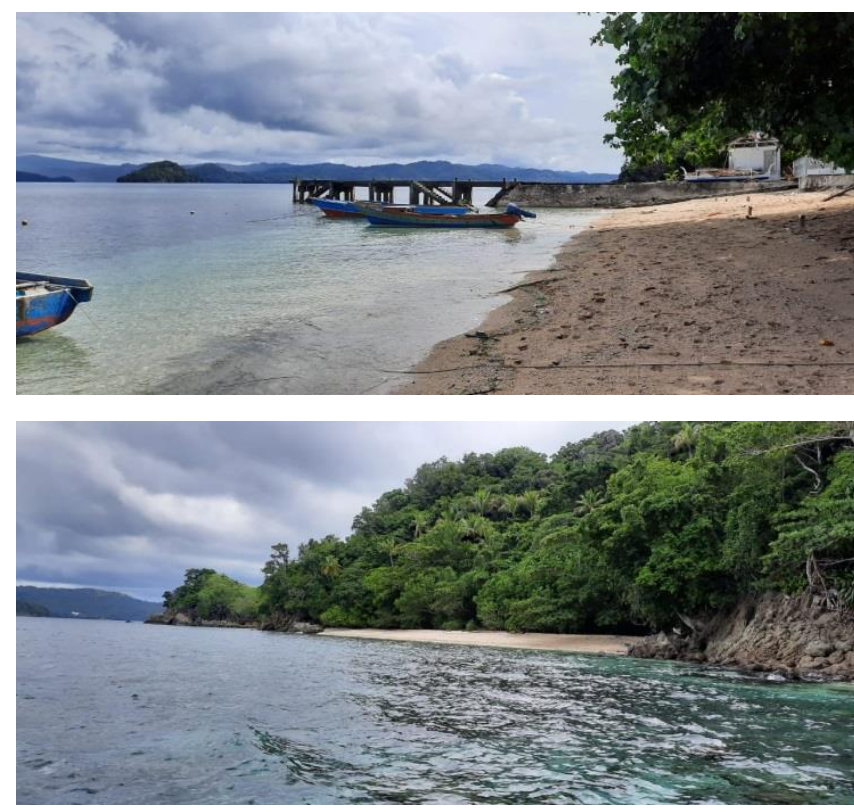

Gambar 3. Pemandangan di wilayah pesisir pantai Pulau Bebalang.

Peluang pengembangan potensi wilayah pesisir di Pulau Bebalang ditunjukkan pada Tabel 2 berikut ini.

Tabel 2. Potensi Pemanfaatan Potensi Wilayah Pesisir di Pulau Bebalang.

\begin{tabular}{|l|l|l|}
\hline $\begin{array}{c}\text { Tipe - tipe } \\
\text { Ekosistem }\end{array}$ & $\begin{array}{c}\text { Potensi } \\
\text { Pemanfaatan } \\
\text { Jasa } \\
\text { Ekonomi }\end{array}$ & Potensi Ancaman \\
\hline $\begin{array}{l}\text { Pantai } \\
\text { berpasir }\end{array}$ & $\begin{array}{l}\text { Rekreasi \& } \\
\text { Konservasi }\end{array}$ & $\begin{array}{l}\text { Perusakan habitat, } \\
\text { Tambang pasir }\end{array}$ \\
\hline Pulau kecil & $\begin{array}{l}\text { Pariwisata, } \\
\text { Tour \& } \\
\text { Travel, } \\
\text { Pemukiman, } \\
\text { Marikultur }\end{array}$ & $\begin{array}{l}\text { Limbah; penduduk } \\
\text { padat; penebangan } \\
\text { vegetasi, pemanasan } \\
\text { global, lenyapnya } \\
\text { pulau - pulau kecil } \\
\text { akibat kenaikan muka } \\
\text { laut 15 - 19 } \\
\text { mm/tahun. }\end{array}$ \\
& &
\end{tabular}

Dalam kegiatan wisata, juga dapat ditampilkan kekayaan budaya masyarakat di Pulau Bebalang, seperti kuliner (seperti sagu, ikan bakar \& dabu-dabu), tarian adat, dan lain sebagainya. Sehingga, partisipasi masyarakat sangat dibutuhkan dalam hal ini.

Berikut ini merupakan data jumlah wisatawan yang datang berkunjung di Pulau Bebalang, ditunjukkan pada Gambar 4.
Data Wisatawan Pulau Bebalang Tahun 2013 - 2019

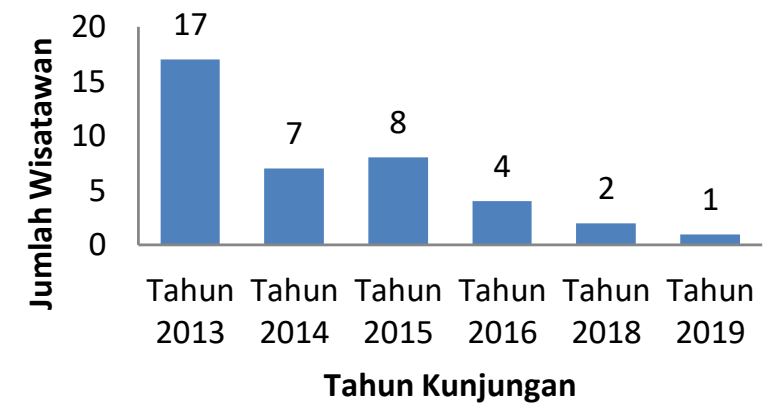

Gambar 4. Data Wisatawan di Pulau Bebalang.

Kunjungan wisatawan di Pulau Bebalang dicatat oleh Pengurus Kampung, sejak Tahun 2013 - 2019. Beberapa kekuatan di Pulau Bebalang yaitu tersedianya air tanah (air tawar) yang cukup melimpah, serta adanya listrik tenaga solar, yang diberikan kuota 4 mata lampu per rumah. Sehingga, kondisi ini menunjang kegiatan wisata yang kondusif di Pulau Bebalang. Namun, beberapa kelemahan di Pulau Bebalang yaitu proses sanitasi belum dapat diatasi dengan baik dimana belum adanya jalur drainase. Sehingga, banyak air tergenang di kompleks perumahan penduduk. Kemudian, pengolahan sampah yang belum dapat diatasi, dimana masyarakat masih suka membuang sampah di pantai. Masyarakat perlu diberi pengetahuan tentang menjaga kebersihan dan kelestarian lingkungan, terutama 3 tonggak penopang kehidupan pesisir yaitu terumbu karang, lamun dan mangrove.

\section{Potensi Bawah Laut Pulau Bebalang}

Potensi bawah laut di Pulau Bebalang, dapat dilihat pada Gambar 5, yaitu kondisi terumbu karang dan padang lamun yang baik untuk dikembangkan dalam kegiatan wisata bahari, seperti snorkeling, diving, dan kegiatan rekreasi lainnya. 


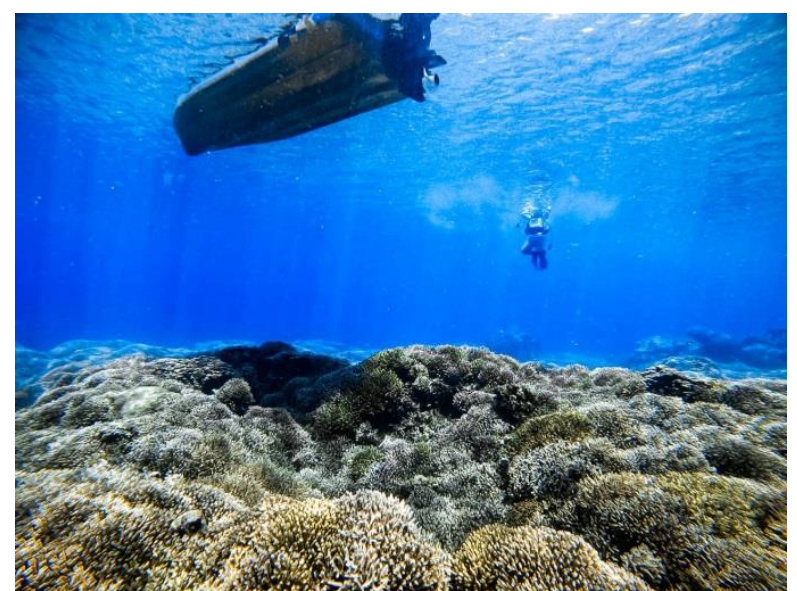

Gambar 5. Potensi bawah laut di Pulau Bebalang (Foto: Ucil Aatjin).

Peluang pengembangan potensi bawah laut di Pulau Bebalang ditunjukkan pada Tabel 3 berikut ini.

Tabel 3. Potensi Pemanfaatan Potensi Bawah Laut di Pulau Bebalang.

\begin{tabular}{|l|l|l|}
\hline $\begin{array}{c}\text { Tipe }- \text { tipe } \\
\text { Ekosistem }\end{array}$ & $\begin{array}{c}\text { Potensi } \\
\text { Pemanfaatan Jasa } \\
\text { Ekonomi }\end{array}$ & Potensi Ancaman \\
\hline $\begin{array}{l}\text { Terumbu } \\
\text { karang }\end{array}$ & $\begin{array}{l}\text { Konservasi, } \\
\text { Pariwisata, } \\
\text { Perikanan, serta } \\
\text { Perlindungan } \\
\text { pantai }\end{array}$ & $\begin{array}{l}\text { Tangkapan ikan } \\
\text { berlebihan, racun } \\
\text { ikan, pemboman, } \\
\text { penambangan } \\
\text { karang, erosi dari } \\
\text { penggundulan } \\
\text { vegetasi di } \\
\text { daratan. Jika } \\
\text { terumbu karang } \\
\text { rusak, maka } \\
\text { tangkapan } \\
\text { menurun. }\end{array}$ \\
& & $\begin{array}{l}\text { Tangkapan ikan } \\
\text { berlebih dan } \\
\text { perusakan karang } \\
\text { dan mangrove }\end{array}$ \\
\hline $\begin{array}{l}\text { Padang } \\
\text { lamun }\end{array}$ & Sumber makanan & \\
& &
\end{tabular}

\section{Analisis SWOT Pengembangan Pulau Bebalang}

Berdasarkan potensi pemanfaatan Pulau Bebalang, analisis SWOT untuk potensi dan pengembangan di Pulau Bebalang dapat dilihat pada Tabel berikut ini. Pada Tabel 4, dapat dilihat Matrik Internal Factor Analysis Summary (IFAS). Dan, pada Tabel 5 merupakan Matrik External Factor Analysis Summary (EFAS).
Tabel 4. Matrik Internal Factor Analysis Summary (IFAS)

\begin{tabular}{|c|c|c|c|c|c|}
\hline \multicolumn{3}{|c|}{ FAKTOR INTERNAL } & Nilai & Bobot & $\begin{array}{c}\text { Nilai } \\
\text { Tertimb } \\
\text { ang }\end{array}$ \\
\hline \multirow{7}{*}{ 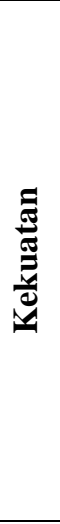 } & 1 & $\begin{array}{l}\text { Pantai } \\
\text { Berpasir }\end{array}$ & 5 & 0,12 & 0,61 \\
\hline & 2 & $\begin{array}{l}\text { Terumbu } \\
\text { karang }\end{array}$ & 5 & 0,12 & 0,61 \\
\hline & 3 & $\begin{array}{l}\text { Padang } \\
\text { Lamun }\end{array}$ & 5 & 0,12 & 0,61 \\
\hline & 4 & Pulau Kecil & 5 & 0,12 & 0,61 \\
\hline & 5 & Perikanan & 5 & 0,12 & 0,61 \\
\hline & 6 & $\begin{array}{c}\text { Air tanah } \\
\text { cukup tersedia }\end{array}$ & 4 & 0,10 & 0,39 \\
\hline & 7 & $\begin{array}{l}\text { Kecukupan } \\
\text { Listrik }\end{array}$ & 3 & 0,07 & 0,22 \\
\hline \multirow{6}{*}{ 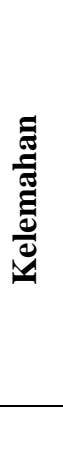 } & 1 & Lokasi jauh & 2 & 0,05 & 0,10 \\
\hline & 2 & $\begin{array}{l}\text { Rendanya } \\
\text { tingkat } \\
\text { pendidikan }\end{array}$ & 2 & 0,05 & 0,10 \\
\hline & 3 & Sanitasi & 2 & 0,05 & 0,10 \\
\hline & 4 & Sampah & 2 & 0,05 & 0,10 \\
\hline & 5 & $\begin{array}{l}\text { Sulitnya } \\
\text { mendapatkan } \\
\text { BBM }\end{array}$ & 1 & 0,02 & 0,02 \\
\hline & & Jumlah & 41 & 1,00 & 4,07 \\
\hline
\end{tabular}

Berdasarkan pada Tabel 4, menunjukkan bahwa kekuatan utama dari Pulau Bebalang yaitu pantai berpasir, ekosistem terumbu karang, padang lamun, pulau kecil, serta potensi perikanan, dengan nilai tertimbang tertinggi sebesar 0,61. Sedangkan, yang menjadi kelemahan utama pulau Bebalang yaitu lokasi yang jauh dimana keterbatasan akses transportasi, rendahnya tingkat pendidikan, sanitasi, dan sampah, dengan nilai tertimbang sebesar 0,10. Serta, sulit mendapatkan BBM dengan nilai tertimbang terkecil 0,02. Berdasarkan hasil perhitungan pada Tabel 4, diperoleh total bobot skor sebesar 4,07. Hal ini berarti bahwa Pulau Bebalang mempunyai posisi internal yang kuat, namun adanya kelemahan yang belum dapat diatasi dengan baik. 
Tabel 5. Matrik External Factor Analysis Summary (EFAS).

\begin{tabular}{|c|c|c|c|c|c|}
\hline & \multicolumn{2}{|c|}{$\begin{array}{c}\text { FAKTOR } \\
\text { EKSTERNAL }\end{array}$} & Nilai & Bobot & $\begin{array}{c}\text { Nilai } \\
\text { Tertimba } \\
\text { ng } \\
\end{array}$ \\
\hline \multirow{5}{*}{ 禺 } & 1 & $\begin{array}{l}\text { Ekowi } \\
\text { sata }\end{array}$ & 5 & 0,15 & 0,76 \\
\hline & 2 & Rekreasi & 5 & 0,15 & 0,76 \\
\hline & 3 & Konservasi & 5 & 0,15 & 0,76 \\
\hline & 4 & $\begin{array}{l}\text { Perlindungan } \\
\text { Pantai }\end{array}$ & 5 & 0,15 & 0,76 \\
\hline & 5 & Marikultur & 4 & 0,12 & 0,48 \\
\hline \multirow{7}{*}{ 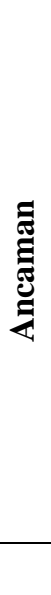 } & 1 & $\begin{array}{l}\text { Perusakan } \\
\text { Habitat }\end{array}$ & 2 & 0,06 & 0,12 \\
\hline & 2 & Overfishing & 2 & 0,06 & 0,12 \\
\hline & 3 & $\begin{array}{l}\text { Perusakan } \\
\text { karang \& } \\
\text { Mangrove }\end{array}$ & 2 & 0,06 & 0,12 \\
\hline & 4 & $\begin{array}{l}\text { Racun } \\
\text { ikan/Pembom } \\
\text { an }\end{array}$ & 1 & 0,03 & 0,03 \\
\hline & 5 & $\begin{array}{l}\text { Penebangan } \\
\text { vegetasi }\end{array}$ & 1 & 0,03 & 0,03 \\
\hline & 6 & $\begin{array}{l}\text { Pemanasan } \\
\text { Global }\end{array}$ & 1 & 0,03 & 0,03 \\
\hline & & Jumlah & 33 & 1,00 & 3,97 \\
\hline
\end{tabular}

Berdasarkan pada Tabel 5, menunjukkan bahwa peluang utama dari Pulau Bebalang yaitu Ekowisata (wisata bahari), Rekreasi, Konservasi, dan Perlindungan Pantai dengan nilai tertimbang tertinggi mencapai 0,76 . Sedangkan, yang menjadi ancaman utama pulau Bebalang yaitu perusakan habitat, Overfishing, serta perusakan karang \& mangrove, dengan nilai tertimbang 0,12. Racun ikan/Pemboman, penebangan vegetasi \& pemanasan global memperoleh nilai tertimbang terkecil sebesar 0,03. Berdasarkan hasil perhitungan pada Tabel 8, diperoleh total bobot skor sebesar 3,97. Artinya, Pulau Bebalang mempunyai peluang yang besar dalam pengembangannya, namun perlu juga memperhatikan adanya ancaman di balik setiap Peluang. 
Tabel 6. Matriks SWOT

\begin{tabular}{|c|c|c|}
\hline & Kekuatan: & Kelemahan: \\
\hline & $\begin{array}{ll}\text { 1. } & \text { Pantai berpasir } \\
\text { 2. } & \text { Terumbu karang } \\
\text { 3. } & \text { Padang lamun } \\
\text { 4. } & \text { Pulau kecil } \\
\text { 5. } & \text { Perikanan } \\
\text { 6. } & \text { Ketersediaan air tanah } \\
\text { 7. } & \text { Kecukupan listrik }\end{array}$ & $\begin{array}{ll}\text { 1. } & \text { Lokasi jauh } \\
\text { 2. } & \text { Rendahnya tingkat } \\
\text { pendidikan } \\
\text { 3. Sanitasi } \\
\text { 4. Sampah } \\
\text { 5. Sulit mendapatkan BBM }\end{array}$ \\
\hline Peluang: & STRATEGI SO & STRATEGI WO \\
\hline $\begin{array}{ll}\text { 1. } & \text { Ekowisata Rekreasi } \\
\text { 2. } & \text { Konservasi } \\
\text { 3. } & \text { Perlindungan pantai } \\
\text { 4. } & \text { Marikultur }\end{array}$ & $\begin{array}{l}\text { 1. Pengembangan wisata bahari } \\
\text { 2. Tour \& Travel } \\
\text { 3. Penyusunan dokumen kunjungan } \\
\text { wisata yang lengkap, jelas dan } \\
\text { terintegrasi dengan data Kabupaten. } \\
\text { 4. Pengembangan usaha budidaya ikan } \\
\text { air laut, udang, kepiting, mutiara, } \\
\text { dan lain-lain. }\end{array}$ & $\begin{array}{l}\text { 1. Memfasilitasi pengadaan } \\
\text { sarana transportasi } \\
\text { 2. Membantu memfasilitasi } \\
\text { pendidikan anak-anak ke } \\
\text { Tingkat Sekolah Menengah, } \\
\text { bahkan Perguruan Tinggi. } \\
\text { 3. Pembuatan saluran drainase } \\
\text { 4. Pengolahan sampah } \\
\text { 5. Membantu suplai BBM }\end{array}$ \\
\hline Ancaman: & STRATEGI ST & STRATEGI WT \\
\hline 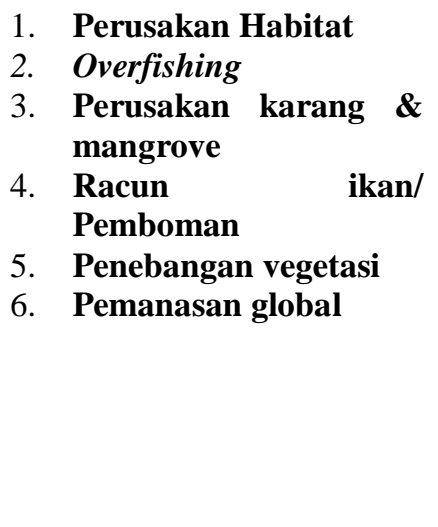 & $\begin{array}{l}\text { 1. Pengawasan pemanfaatan } \\
\text { terumbu karang, lamun \& } \\
\text { mangrove oleh Dinas Kelautan } \\
\text { dan Perikanan Kabupaten } \\
\text { Kepulauan Sangihe. } \\
\text { 2. Sosialisasi } 3 \text { tonggak penopang } \\
\text { ekosistem wilayah pesisir: } \\
\text { terumbu karang, lamun \& } \\
\text { mangrove kepada Perangkat } \\
\text { Kampung \& masyarakat. } \\
\text { 3. Pembentukan kelompok nelayan } \\
\text { yang mengawas pemanfaatan } \\
\text { potensi alam di Pulau Bebalang. }\end{array}$ & $\begin{array}{l}\text { 1. Memberikan pengetahuan } \\
\text { terkait pentingnya menjaga } 3 \\
\text { tonggak penopang ekosistem } \\
\text { pesisir (terumbu karang, lamun } \\
\text { \& mangrove). } \\
\text { 2. Memperhatikan kesejahteraan } \\
\text { guru - guru yang mengajar di } \\
\text { pulau kecil perbatasan } \\
\text { 3. Membantu suplai BBM ke } \\
\text { wilayah kecamatan dengan } \\
\text { harga subsidi khusus untuk } \\
\text { nelayan } \\
\text { 4. Pengolahan sampah plastik }\end{array}$ \\
\hline
\end{tabular}

Peta pengembangan potensi di Pulau Bebalang dalam matriks SWOT di atas, menjadi bahan masukan bagi Pemerintah Daerah dalam pengembangan dan pengelolaan wilayah pesisir dan pulau - pulau kecil di Kabupaten Kepulauan Sangihe.

\section{Kajian Sosial Ekonomi Masyarakat dalam Pengembangan Potensi Pulau Bebalang}

Peran masyarakat Pulau Bebalang dalam pemanfaatan potensi wilayah yang ada, sangat penting. Menurut Sugianto (2016), budaya dan perilaku masyarakat menjadi modal penting dalam pengembangan desa wisata, dan utamanya berdampak pada peningkatan ekonomi masyarakat. Menurut
Gunawan, et al. (2013), 3 komponen dalam zona pemanfaatan suatu wilayah yaitu memperhatikan aspek ekologi, sosial dan ekonomi, seperti yang ditunjukkan pada Gambar 7. Dalam hal ini, pentingnya memperhatikan aspek ekologi yaitu kondisi lingkungan, sosial dan ekonomi bagi masyarakat di Pulau Bebalang. Pemberdayaan masyarakat dalam pemanfaatan jasa ekonomi di Pulau Bebalang, dilakukan oleh Pemerintah Daerah, dalam hal ini ditangani oleh Dinas Pariwisata, dan Pemerintah Kampung. 


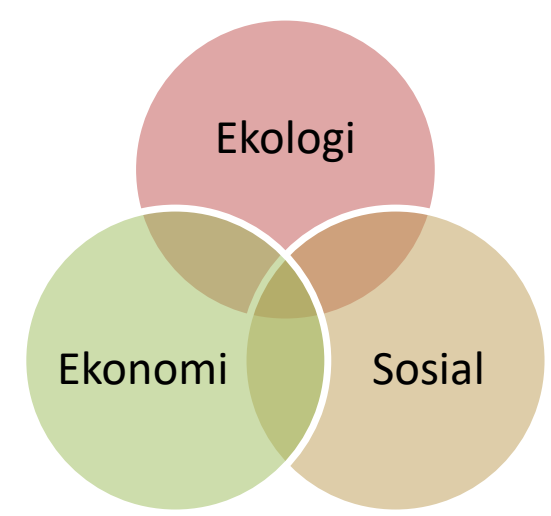

Gambar 7. Bagan Pemanfaatan Wilayah

Menurut BPS Kabupaten Boyolali (2009) dalam Gunawan, et al. (2013), tingkat pendidikan masyarakat juga menjadi faktor penting dalam keberhasilan pengembangan suatu wilayah, dimana persepsi masyarakat mempengaruhi penerimaan inovasi dalam suatu program pengembangan wilayah. Sebagian besar tingkat pendidikan masyarakat di Pulau Bebalang adalah Sekolah Dasar (SD). Sehingga, masyarakat perlu diberi pengetahuan tentang ekosistem wilayah pesisir dan bagaimana menjaga keberlangsungan potensi alam yang ada. Hal ini juga selaras dengan Okoseray, et al. (2017) bahwa tingkat pengetahuan masyarakat tentang manfaat ekosistem pesisir masih kurang sehingga mengakibatkan kurangnya peran masyarakat dalam pengelolaan wilayah pesisir. Sehingga, pentingnya sosialisasi bagi masyarakat tentang pengelolaan dan pelestarian ekosistem pesisir. Hal yang paling mendasar adalah menjaga kebersihan lingkungan, menjaga nilai nilai budaya serta adat istiadat di Pulau Bebalang sebagai kekayaan budaya, serta meningkatkan kemampuan menggunakan Bahasa Inggris secara sederhana melalui belajar percakapan sehari - hari. Salah satu budaya yang ada di Pulau Bebalang yaitu "Soma Kongkong", yaitu jaring insang permukaan yang digunakan untuk menangkap ikan pelagis. Jaring tersebut merupakan hasil urunan dari beberapa keluarga untuk membeli alat tangkap dan perahu. Hasil tangkapan dibagi, selain kepada tiap keluarga dalam kelompok, juga dibagikan kepada ibu - ibu janda dan anak - anak yatim piatu.

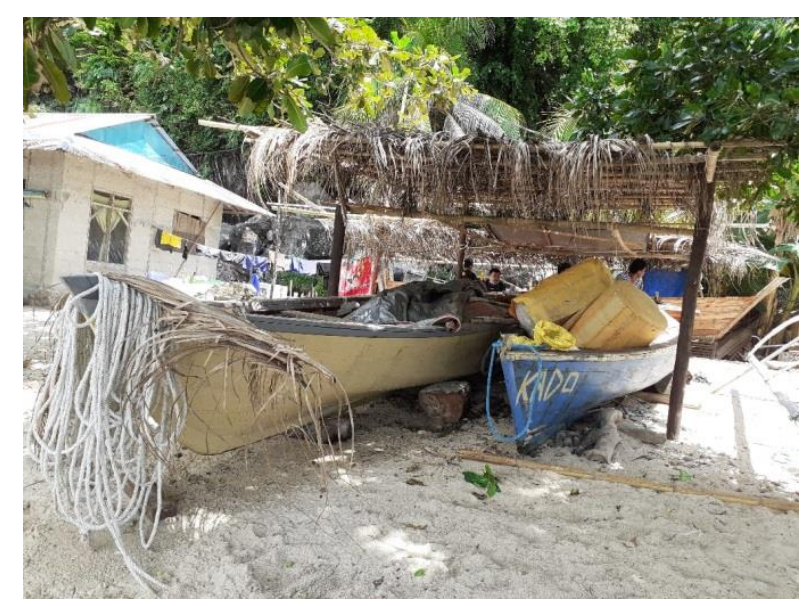

Gambar 8. Soma Kongkong dan kedua perahu yang digunakan.

Sebagian besar masyarakat di Pulau Bebalang mempunyai pekerjaan sebagai nelayan. Hal ini menunjukkan bahwa mereka sangat menggantungkan hidup mereka di laut. Masyarakat dapat diedukasi, sebagai pengguna kekayaan alam laut, namun mereka juga menjadi pelopor dalam menjaga kelestarian lingkungan. Masyarakat sendiri yang berperan aktif dalam pengelolaan dan pemanfaatan lingkungan. Pemerintah Kampung dapat membentuk kelompok nelayan yang bertugas untuk mengawasi pemanfaatan potensi sumber daya alam pesisir dan bawah laut di Pulau Bebalang.

\section{KESIMPULAN}

Pemanfaatan sumber daya alam pesisir dan bawah laut di Pulau Bebalang merupakan gabungan aspek lingkungan, sumber daya manusia, serta faktor sosial ekonomi masyarakat. Potensi wilayah pesisir seperti pantai berpasir, serta potensi bawah laut di Pulau Bebalang seperti kekayaan terumbu karang dan lamun, dapat dikembangkan ke berbagai bidang seperti wisata bahari, tour \& travel, konservasi, dan lain sebagainya. Namun, perlu juga memperhatikan adanya ancaman. Rekomendasi strategi untuk pengembangan potensi Pulau Bebalang berada pada kuadaran I artinya Progresif. Hal ini menunjukkan bahwa pengembangan potensi Pulau Bebalang dalam kondisi prima dan 
mantap sehingga dapat berkembang lebih maju. Kondisi ini memungkinkan dalam peningkatan pendapatan masyarakat sambil tetap menjaga kelestarian lingkungan.

\section{DAFTAR RUJUKAN}

Arif, A. 2008. Pengaturan Hukum dalam Mewujudkan Pengelolaan Wilayah Pesisir yang Berbasis Masyarakat di Kabupaten Rembang. Tesis. Program Magister Ilmu Hukum Program Pascasarjana Universitas Diponegoro: Semarang

Badan Pusat StatistikKabupatenKepulauanSangihe. 2019. Kecamatan Manganitu Selatan dalam Angka 2019. BPS Kabupaten Kepulauan Sangihe: Tahuna

Bungin, H. M. Burhan. 2008. PenelitianKualitatif: Komunikasi, Ekonomi, KebijakanPublik, dan IlmuSosialLainnya. Kencana: Jakarta

Dahuri, R., Rais, J., Ginting, S. P., \& Sitepu, M. J. 2008. Pengelolaan Sumber Daya Wilayah Pesisir dan Lautan Secara Terpadu. Pradnya Paramita: Jakarta

Gunawan, H., Bismark, M., \& Krisnawati, H. 2013. Kajian Sosial Ekonomi Masyarakat Sekitar Sebagai Dasar Penetapan Tipe Penyangga Taman Nasional Gunung Merbabu, Jawa Tengah. Jurnal Penelitian Hutan dan Konservasi Alam, 10(2): 103 - 119

Hermawan, H. 2017. Pengembangan Destinasi Wisata pada Tingkat Tapak Lahan dengan Pendekatan Analisis Swot. Jurnal Pariwisata, Vol. 4 (2), Hal. $64-74$

Manoppo, L. 2014. Optimalisasi Pengelolaan Sumberdaya Ikan Selar (Selaroides leptoplepis) Melalui Penguatan Kearifan Lokal Melombo di Desa Salurang Kabupaten Kepulauan Sangihe. Disertasi. Program Doktor Ilmu - ilmu Pertanian Minat Pengelolaan Sumberdaya Alam dan Lingkungan Program Pascasarjana Fakultas Pertanian Universitas Brawijaya: Malang
Okoseray, K. M., Widiastuti, N., \& Parenden, D. 2017. Pemanfaatan, Persepsi dan Partisipasi Masyarakat Terhadap Pelestarian Ekosistem Pesisir di Distrik Manokwari Selatan. Jurnal Sumberdaya Akuatik Indopasifik, 1(1): 93 104

Rangkuti, F. 2006. Analisis SWOT Teknik Membedah Kasus Bisnis. Gramedia Pustaka Utama: Jakarta

Satria, A. 2015. Pengantar Sosiologi Masyarakat Pesisir. Yayasan Pustaka Obor Indonesia: Jakarta

Satria, D. 2009. Strategi Pengembangan Ekowisata Berbasis Ekonomi Lokal dalam Rangka Program Pengentasan Kemiskinan di Wilayah Kabupaten Malang. Journal of Indonesian Applied Economics, Vol. 3 (1), $34-47$

Stanis, S. 2005. Pengelolaan Sumberdaya Pesisir dan Laut Melalui Pemberdayaan Kearifan Lokal di Kabupaten Lembata Propinsi Nusa Tenggara Timur. Tesis. Program Studi Manajemen Sumberdaya Pantai Program Pascasarjana Universitas Diponegoro: Semarang

Sugianto, A. 2016. Kajian Potensi Desa Wisata Sebagai Peningkatan Ekonomi Masyarakat Desa Karang Patihan Kecamatan Balong Ponorogo. Jurnal Ekuilibrium, 11(1): 56 - 65

Sulistyo, A. 2017. Analisis SWOT 8-K pada Objek Wisata Rekreasi dan Hiburan Keluarga Kid's Fun Yogyakarta. Jurnal Kepariwisataan, Vol. 11 (2), Hal. 1 - 10

Sutrisno, E. 2014. Implementasi Pengelolaan Sumber Daya Pesisir Berbasis Pengelolaan Wilayah Pesisir Secara Terpadu untuk Kesejahteraan Nelayan (Studi di Perdesaan Nelayan Cangkol Kelurahan Lemahwungkuk Kecamatan Lemahwungkuk Kota Cirebon). Jurnal Dinamika Hukum, Vol. 14 (1), 1-12

UU RI Nomor 27 Tahun 2007 tentang Pengelolaan Wilayah Pesisir dan Pulau - pulau Kecil.

Wahyudin, Y. 2015. Sistem Sosial Ekonomi dan Budaya Masyarakat Pesisir. Materi disampaikan pada Pelatihan Pengelolaan Kawasan Konservasi Perairan, tanggal 5 Desember 2003, di Kampus Pusat Diklat Kehutanan 